\title{
Analysis of the Factors Affecting Recurrence and Postoperative Incontinence after Surgical Treatment of Anal Fistula: A Retrospective Cohort Study
}

\author{
Anal Fistülün Cerrahi Tedavisi Sonrası Nüks ve Postoperatif İnkontinansı \\ Etkileyen Faktörlerin Analizi: Retrospektif Bir Kohort Çalışması
}

\author{
(1) Mehmet Arif Usta \\ Karadeniz Technical University Faculty of Medicine, Department of General Surgery, Trabzon, Turkey
}

\section{|IIIIIII| ABSTRACT}

Aim: Surgical treatment of anal fistula in association with the high rates of recurrence and faecal incontinence is a problematic issue. The complexity of this disease and the diversity of available surgical techniques are the essential factors affecting the outcomes of the treatment. We aimed to assess the rates of recurrence and faecal incontinence as well as the risk factors that affect these outcomes among patients in a single institution.

Method: All consecutive patients with cryptoglandular anal fistula who underwent anal fistulotomy or seton placement were retrospectively evaluated during January 2016 and December 2019. The demographic and clinical features, including the Parks' and St. James' classifications, the number of surgical procedures, recurrence of fistula and the development and type of faecal incontinence based on the Wexner's score were evaluated. The recurrence and postoperative incontinence were considered as the primary outcomes of this study.

Results: A total of 98 patients of mean age $45.9 \pm 13.4$ years (male to female ratio: 2.92 ) were enrolled in this study. Fistulotomy and seton placement were performed in $53(54.1 \%)$ and 45 patients (45.9\%), respectively. There were a total of 9 recurrences (9.2\%). The age of the patients with recurrence was significantly lower $(\mathrm{p}=0.044)$. Postoperative incontinence developed in 11 patients $(11.2 \%)$. No permanent solid or flatus type of incontinence was noted. No significant impact of the demographic and clinical variables on the development of recurrence and incontinence was noted ( $p>0.05$ for all). For patients with fistulotomy $(n=53)$ and seton placement $(n=45)$, five and 67 extra surgical procedures, respectively, were involved. During the median follow-up time of 33 months, the healing rates after fistulotomy and seton placement were $100 \%$.

Conclusion: The recurrence and postoperative incontinence were not influenced by patient, surgery and fistula-related factors. It is therefore feasible to treat anal fistula by using different surgical approaches with acceptable rates of recurrence and incontinence. In fact, a staged surgical approach including serial seton placements followed by fistulotomy may be a reliable technique in appropriate patients.

Keywords: Anal fistula, recurrence, faecal incontinence, surgery

\section{|IIIIIII|| ÖZ}

Amaç: Anal fistülün cerrahi tedavisi yüksek nüks oranları ve fekal inkontinans nedeniyle sorunlu bir konudur. Hastalığın karmaşıklığı ve cerrahi tekniklerin çeşitliliği, tedavinin sonuçlarını etkileyen temel faktörlerdir. Tek kuruma ait nüks ve dışkı inkontinansı oranlarını ve bu sonuçları etkileyen risk faktörlerini değerlendirmeyi amaçladık.

Yöntem: Ocak 2016 ile Aralık 2019 tarihleri arasında anal fistülotomi veya seton uygulaması yapılan kriptoglandüler anal fistülü olan ardışık tüm hastalar retrospektif olarak değerlendirildi. Parks' ve St James' sınıflandırmaları, cerrahi prosedürlerin sayısı, fistül nüksü ve Wexner skoruna göre fekal inkontinans gelişimi ve tipi dahil olmak üzere demografik ve klinik özellikler değerlendirildi. Nüks ve postoperatif inkontinans çalışmanın birincil çıkarım noktalarıydı.

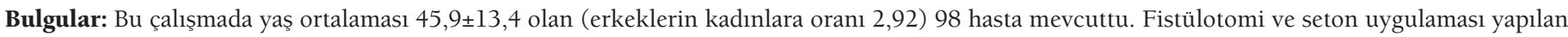
hasta sayıları sırasıyla $53(\% 54,1)$ ve $45(\% 45,9)$ idi. Dokuz hastada nüks vardı $(\% 9,2)$. Rekürrens gelişen hastaların yaşı anlamlı olacak şekilde daha düşüktü $(\mathrm{p}=0,044)$. Ameliyat sonrası 11 hastada $(\% 11,2)$ inkontinans gelişti. Kalıcı katı veya gaz tipi inkontinans tespit edilmedi. Demografik ve klinik değişkenlerin nüks ve inkontinans gelişimi üzerine anlamlı bir etkisi yoktu (bütün parametreler için p>0,05). Fistülotomi $(\mathrm{n}=53$ ) ve seton yerleştirme $(n=45)$ uygulanan hastalarda sırasıyla beş ve 67 ekstra cerrahi prosedür uygulandığı görüldü. Otuz üç aylık medyan takip süresinde fistülotomi ve seton yerleşimi sonrası iyileşme oranları \%100 idi. 
Sonuç: Rekürrens ve postoperatif inkontinans gelişiminin hasta, cerrahi teknik ve fistül ile ilişkili faktörlerden etkilenmediği görüldü. Kabul edilebilir nüks ve inkontinans oranlarıyla farklı cerrahi yaklaşımlar kullanarak anal fistülü tedavi etmek mümkündür. Seri seton uygulamalarını içeren aşamalı cerrahi yaklaşım ve ardından fistülotomi uygun hastalarda güvenilir bir teknik olabilir.

Anahtar Kelimeler: Anal fistül, rekürrens, fekal inkontinans, cerrahi

\section{Introduction}

An anal fistula is defined as an abnormal connection between the anorectum and anal epithelium. ${ }^{1}$ Besides their important clinical manifestations such as the local pain, purulent discharge and incontinence, the treatment of anal fistula remains a challenging one. ${ }^{1,2}$ The eradication of the fistula tract without the development of recurrence and preservation of the anal sphincter function has been regarded as the goal of the surgical treatment of anal fistula. ${ }^{3}$ However, the high rates of recurrence and faecal incontinence remain a significant problem in association with its surgical treatment. ${ }^{4}$

Different classification systems of anal fistula have been used for decision making to determine the best possible surgical approach. ${ }^{5}$ The Park's system as intersphincteric, transsphincteric, suprasphincteric and extrasphincteric or a simpler classification as low or high in relation to the dentate line has been proposed. ${ }^{5}$ In addition, it can be broadly classified into simple and complex fistulas. ${ }^{6}$ The type of surgical treatment demonstrates great variability, depending on the type of anal fistula. ${ }^{3}$ While a lay-open fistulotomy technique can be employed for intersphincteric or simple/ low transsphincteric anal fistulas, the seton placement method or staged surgeries with extensive or conservative approaches are the techniques selected for complex anal fistulas, including high transsphincteric, suprasphincteric, extrasphincteric and recurrent fistulas., ${ }^{3,8,9,10}$ For select cases, the use of serial setons and interval muscle-cutting fistulotomy has been used to treat complex or recurrent anal fistulas. ${ }^{3}$ However, a clear advantage of one of the technique has not been shown on the healing rate or faecal incontinence. $^{10}$

Previous studies have reported success rates of 35\%-100\%. In these studies, significant variations were noted in the rates of faecal incontinence from $0 \%$ to $62 \%$, depending on the type of fistula and the operation conducted., ${ }^{5,11}$ The complexity of the disease and the diversity of surgical techniques has been postulated as the underlying reasons for such differences. ${ }^{5}$ Therefore, the optimisation of the outcomes for each surgical technique may be an essential step for the establishment of surgical treatment recommendations.

The aim of this study was to assess the outcomes of surgical techniques for anal fistula with due consideration to the rates of recurrence and faecal incontinence as well as the risk factors affecting the outcomes in a single institution.

\section{Materials and Methods}

\section{Study}

This study was a retrospective analysis of all patients who underwent surgical treatment for anal fistula at a tertiary medical centre (university hospital) between January 2016 and December 2019. The study was performed in accordance with the principles of the Declaration of Helsinki. The local ethical committee approved the study (Ethical Committee for Clinical Studies, Karadeniz Techinical University, Faculty of Medicine, 21.01.2015/2020-138). The requirement for written consent from the patients was waived by the local ethical committee due to the retrospective design of the study and the assurance of data anonymity.

\section{Patients}

A total of 116 consecutive patients with cryptoglandular anal fistula were evaluated. The patients with chronic inflammatory bowel disease $(n=7)$, coexisting rectal and anal cancer $(n=2)$, the development of any type of cancer on the fistulous tracts $(\mathrm{n}=2)$ and incomplete follow-up data $(n=7)$ were excluded. Finally, 98 patients with anal fistula were included in the study.

In all patients, preoperative magnetic resonance imaging was performed and analysed by an experienced radiologist and the surgical team together. The Wexner score of 0-20 was applied for preoperative and postoperative assessment of incontinence. ${ }^{11,12}$ Higher scores indicate a higher level of incontinence and vice versa.

The fistulas were classified in accordance with the Parks' and St. James' classification systems. ${ }^{7}$ The fistulas with Grade I for Parks and Grades I-II for St. James' classifications were regarded as simple fistulas. Higher grades (Parks II-IV and St. James III-V) were considered as complex fistulas.

\section{Operative Technique}

The operations were performed for anal fistulotomy, loose seton placement, mucosal advancement flap and drainage of any type of anal abscess when detected. All operations were performed by a member of the specialised colorectal surgical team of the hospital. The type and sequence of the surgical treatment were determined based on the discretion 
of the attending surgeon. As an institutional policy, either fistulotomy or seton placement was performed as the initial surgical treatment based on the type of fistula.

\section{Surgical Technique}

The patients were placed in the prone jack-knife position and subjected to general or spinal anaesthesia. The external and internal openings of the fistula were determined after digital and rectoscopic examinations. Standard fistula probes were used to identify the tract/s. In suspicious cases in which the internal openings were obscure, hydrogen peroxide was injected from the external opening to observe bubbles at the origin of the fistula tract as the internal opening. The skin and subcutaneous tissues starting from the external opening to the nearest point of the muscles of the external sphincter were incised by cauterisation. In case of an abscess or horseshoe extensions, drainage was performed by using a mushroom catheter.

Following the delineation of the fistula tract/s, the mucosa, internal sphincter, involved external sphincter (if it was less than one-third) and the skin between the internal and external openings was cut to perform lay-open anal fistulotomy for the fistulas involving less than one-third area of the external sphincter. This assessment was performed via palpation of the sphincter complex after putting the probe under anaesthesia just before the surgery. In the presence of multiple external openings in the same anal quadrant, the tracts were merged with fistulotomy. More than one fistulotomy was performed for the fistulas with the external openings located at different quadrants. In patients with the fistulas involving more than one-third area of the external sphincter or high/complex types, loose seton placement was performed by using a 2.0 silk thread. All patients were discharged the day after the operation.

\section{Follow-up Studies}

After the discharge of the patients, out-patient followup examinations were performed every 2 weeks. In each examination, the status of wound healing and continence, the position of the seton and abscess formation were recorded. The Wexner score was used to assess the postoperative continence status of the patients.

In patients with seton placement, a second surgery was planned in the postoperative 8 weeks. For the fistulas in which the involvement of the external sphincter was regarded to be less than one-third and no abscess was detected, fistulotomy was performed. In other situations, a second seton was replaced. In the case of non-healing, consecutive anal explorations to perform fistulotomy, serial seton placement or mucosal advancement flap procedures depending on the intraoperative findings were performed.
Face-to-face or telephonic interviews were performed for the final evaluation of the recurrence and continence status at 3-month intervals.

The demographic (age and sex) and clinical data of the patients were collected from the hospital information system. The number and place of fistulous tracts and openings, the type of fistula based on the preoperative magnetic resonance imaging, operative variables, the number of surgical procedures, complications, postoperative healing time following seton placement, recurrence of fistula and the development and type of faecal incontinence were evaluated.

\section{Statistical Analysis}

The primary outcomes were recurrence of anal fistula and any change in the status of postoperative continence for flatus, liquid and formed stool in accordance with the Wexner score.

The recurrence/failure was defined as recurring/persisting fistula in the same region during the follow-up period. The development of a new fistula at a different localisation at the anal region was not considered as a case of recurrence.

Statistical analysis was performed using a commercially available statistical software package (SPSS Inc., Chicago, IL). The Shapiro-Wilk test was applied to determine the normal distribution of continuous variables. The mean \pm standard deviation and/or median (range) were used to express the continuous variables with and without normal distribution, respectively. The categorical variables were expressed as frequencies and percentages. The Pearson's chisquare and/or Fisher's exact tests were used for categorical variables. The Mann-Whitney U test was applied to compare continuous variables without normal distribution. Oneway analysis of variance and Wilcoxon Signed Rank tests was used for the comparison of continuous variables with normal distribution. $\mathrm{P}<0.05$ was considered to be statistically significant.

\section{Results}

The mean age of the patients was $45.9 \pm 13.4$ years, with a male to female ratio of 2.92. A total of 18 patients (18.4\%) underwent anorectal surgery for anal fistula prior to the index admission.

Preoperative imaging revealed presence of coexisting active anal abscess in 30 patients (30.6\%). Based on the Parks' classification, intersphincteric type was the most common type noted in 55 patients (56.1\%). St. James Grade 1 anal fistula was detected in 44 patients (44.9\%). Considering the Parks' and St. James' classifications, a total of 52 (53.1\%) and 46 patients $(46.9 \%)$ with simple and complex anal fistula, respectively, were recorded. The demographic and clinical features of the patients are detailed in Table 1. 
A total of 53 patients (54.1\%) underwent fistulotomy as the initial surgery, whereas seton placement was performed in 45 patients (45.9\%).

During the median follow-up time of 33 months, there were nine recurrences $(9.2 \%)$ in the study group (Table 2 ), with five $(9.4 \%)$ and four recurrences $(8.9 \%)$ in the fistulotomy and primary seton placement groups, respectively. The median time interval for the development of recurrences was 8 months (range: 4-12). The age of the patients with recurrence was significantly lower than that of the patients without recurrences $(p=0.044)$. No significant impact of the variables, including the type of fistula and surgery, was noted on the development of recurrence ( $>0.05$ for all). The second fistulotomy was performed for patients who experienced recurrence after fistulotomy $(n=5)$ and were fully cured. Thus, the healing rate after fistulotomy was $100 \%$ in the present study.

In 11 patients $(11.2 \%)$, a significant increase in the postoperative Wexner score was detected $(\mathrm{p}=0.033$ ) (Table
3). The average Wexner score increased from $0.02 \pm 0.142$ to $0.29 \pm 1.14$. There was no permanent solid or flatus type of incontinence. In 89 patients (90.8\%), the postoperative Wexner score was 0 . Although the median postoperative Wexner score in patients who reported an increase in their Wexner scores was 1 , the scores of 3, 3, 5 and 9 were detected in four patients. The clinical features of the incontinence are summarised in Table 4. The incontinence to flatus was reported more commonly. The demographic and clinical features did not increase the risk of postoperative incontinence ( $p>0.05$ for all; Table 5).

In patients with primary seton placement $(n=45)$, outwards displacement of seton with complete healing was recorded in nine patients (Table 6). During the second exploration, serial seton placement was performed in 23 patients. In 11 and two patients, fistulotomy and flap procedures were, respectively, performed. There were four recurrences, three in the re-seton placement group and one in the fistulotomy group, respectively. The second seton placement was

Table 1. Demographic and clinical features of the study group ( $n=98)$

\begin{tabular}{|c|c|c|}
\hline Variable & & Value \\
\hline Age $(\text { year })^{\dagger}$ & & $45.9 \pm 13.4$ \\
\hline \multirow[t]{2}{*}{$\operatorname{Sex}^{\ddagger}$} & Female & $25(25.5)$ \\
\hline & Male & $73(74.5)$ \\
\hline Recurrent fistula $^{\ddagger}$ & Yes & $18(18.4)$ \\
\hline Coexisting abscess ${ }^{\ddagger}$ & Yes & $30(30.6)$ \\
\hline \multirow{2}{*}{ Type of fistula ${ }^{\ddagger}$} & Simple & $52(53.1)$ \\
\hline & Complex & $46(46.9)$ \\
\hline \multirow{2}{*}{ Number of tracks ${ }^{\ddagger}$} & Single & 93 (94.9) \\
\hline & Multiple & $5(5.1)$ \\
\hline \multirow{3}{*}{ Parks classification ${ }^{\dagger}$} & Intersphincteric & $55(56.1)$ \\
\hline & Transsphincteric & $36(36.7)$ \\
\hline & Suprasphincteric & $7(7.1)$ \\
\hline \multirow{5}{*}{ St James's classification ${ }^{\ddagger}$} & Grade 1 ( simple linear intersphincteric) & $44(44.9)$ \\
\hline & Grade 2 (intersphincteric with abscess or secondary tract) & $11(11.2)$ \\
\hline & Grade 3 (transsphincteric) & $19(19.4)$ \\
\hline & $\begin{array}{l}\text { Grade } 4 \text { (transsphincteric with abscess or secondary tract within } \\
\text { the ischiorectal fossa) }\end{array}$ & $16(16.3)$ \\
\hline & Grade 5 (supralevator and translevator extension) & $8(8.2)$ \\
\hline \multirow{2}{*}{ Type or surgery ${ }^{\ddagger}$} & Fistulotomy & $53(54.1)$ \\
\hline & Seton & $45(45.9)$ \\
\hline Follow-up interval (months) & & $21(13-33)$ \\
\hline
\end{tabular}


Table 2. Association of demographic and clinical features of the patients with and without recurrence

\begin{tabular}{|c|c|c|c|c|}
\hline Variable & & With recurrence $(n=9)$ & $\begin{array}{l}\text { Without recurrence } \\
(\mathrm{n}=89)\end{array}$ & $\mathrm{p}$ \\
\hline Age (year) ${ }^{\dagger}$ & & $37.3 \pm 9.6$ & $46.7 \pm 13.8$ & 0.044 \\
\hline \multirow{2}{*}{$\operatorname{Sex}^{\ddagger}$} & Female & $1(11.1)$ & $24(27.0)$ & \multirow[t]{2}{*}{0.441} \\
\hline & Male & $8(88.9)$ & $65(73.0)$ & \\
\hline \multirow{2}{*}{ Previous fistula surgery ${ }^{\ddagger}$} & Yes & $1(11.1)$ & $17(19.1)$ & \multirow[t]{2}{*}{1.0} \\
\hline & No & $8(88.9)$ & $72(80.9)$ & \\
\hline \multirow{2}{*}{ Coexisting abscess ${ }^{\ddagger}$} & Yes & $3(33.3)$ & $27(30.3)$ & \multirow[t]{2}{*}{1.0} \\
\hline & No & $6(66.7)$ & $62(69.7)$ & \\
\hline \multirow{2}{*}{ Type of fistula ${ }^{\ddagger}$} & Simple & $5(55.6)$ & $47(52.8)$ & \multirow[t]{2}{*}{1.0} \\
\hline & Complex & $4(44.4)$ & $42(47.2)$ & \\
\hline \multirow{2}{*}{ Number of tracts $^{\ddagger}$} & Single & $9(100)$ & $84(94.4)$ & \multirow[t]{2}{*}{1.0} \\
\hline & Multiple & $0(0)$ & $5(5.6)$ & \\
\hline \multirow{3}{*}{ Parks classification $^{\ddagger}$} & Intersphincteric & $5(55.6)$ & $50(56.2)$ & \multirow[t]{3}{*}{0.648} \\
\hline & Transsphincteric & $4(44.4)$ & $32(36.0)$ & \\
\hline & Suprasphincteric & $0(0)$ & $7(7.9)$ & \\
\hline \multirow{5}{*}{ St James's classification ${ }^{\ddagger}$} & Grade 1 & $3(33.3)$ & $41(46.1)$ & \multirow[t]{5}{*}{0.658} \\
\hline & Grade 2 & $2(22.2)$ & $9(10.1)$ & \\
\hline & Grade 3 & $2(22.2)$ & $17(19.1)$ & \\
\hline & Grade 4 & $2(22.2)$ & $14(15.7)$ & \\
\hline & Grade 5 & $0(0)$ & $8(9.0)$ & \\
\hline \multirow{2}{*}{ Type or surgery ${ }^{\ddagger}$} & Fistulotomy & $5(55.6)$ & $48(53.9)$ & \multirow[t]{2}{*}{1.0} \\
\hline & Seton & $4(44.4)$ & $41(46.1)$ & \\
\hline
\end{tabular}

$\dagger:$ Mean \pm standard deviation, $\ddagger: \mathrm{n}(\%)$

Table 3. Changes in the preoperative and postoperative Wexner scores of the patients

$\begin{array}{llll}\text { Variable } & \text { Preoperative } & \text { Postoperative } & \text { p } \\ \text { Wexner score }^{\dagger, \S} & 0.02 \pm 0.142 / 0(0-1) & 0.29 \pm 1.14 / 0(0-9) & 0.003\end{array}$

$\dagger$ : Mean \pm standard deviation, §: Median (range)

Table 4. Details of the postoperative incontinence $(n=11)$ following surgical treatment of anal fistula based on the Wexner score

\begin{tabular}{|c|c|c|c|c|c|}
\hline & & & Frequency & & \\
\hline Type of incontinence & Never & Rarely & Sometimes & Usually & Always \\
\hline Solid & 0 & 0 & 0 & 0 & 0 \\
\hline Liquid & 0 & 1 & 1 & 1 & 0 \\
\hline Flatus & 0 & 7 & 2 & 1 & 0 \\
\hline Wears pad & 0 & 0 & 0 & 2 & 0 \\
\hline Lifestyle alterations & 0 & 0 & 1 & 1 & 0 \\
\hline
\end{tabular}

Never: No episode in the past 4 weeks; rarely, 1 episode in the past 4 weeks; sometimes: $>1$ episode in the past 4 weeks, but <1 a week; usually 1 or more episodes a week but $<1$ a day; always: 1 or more episodes a day 
Table 5. Association of demographic and clinical features of the patients with and without postoperative incontinence

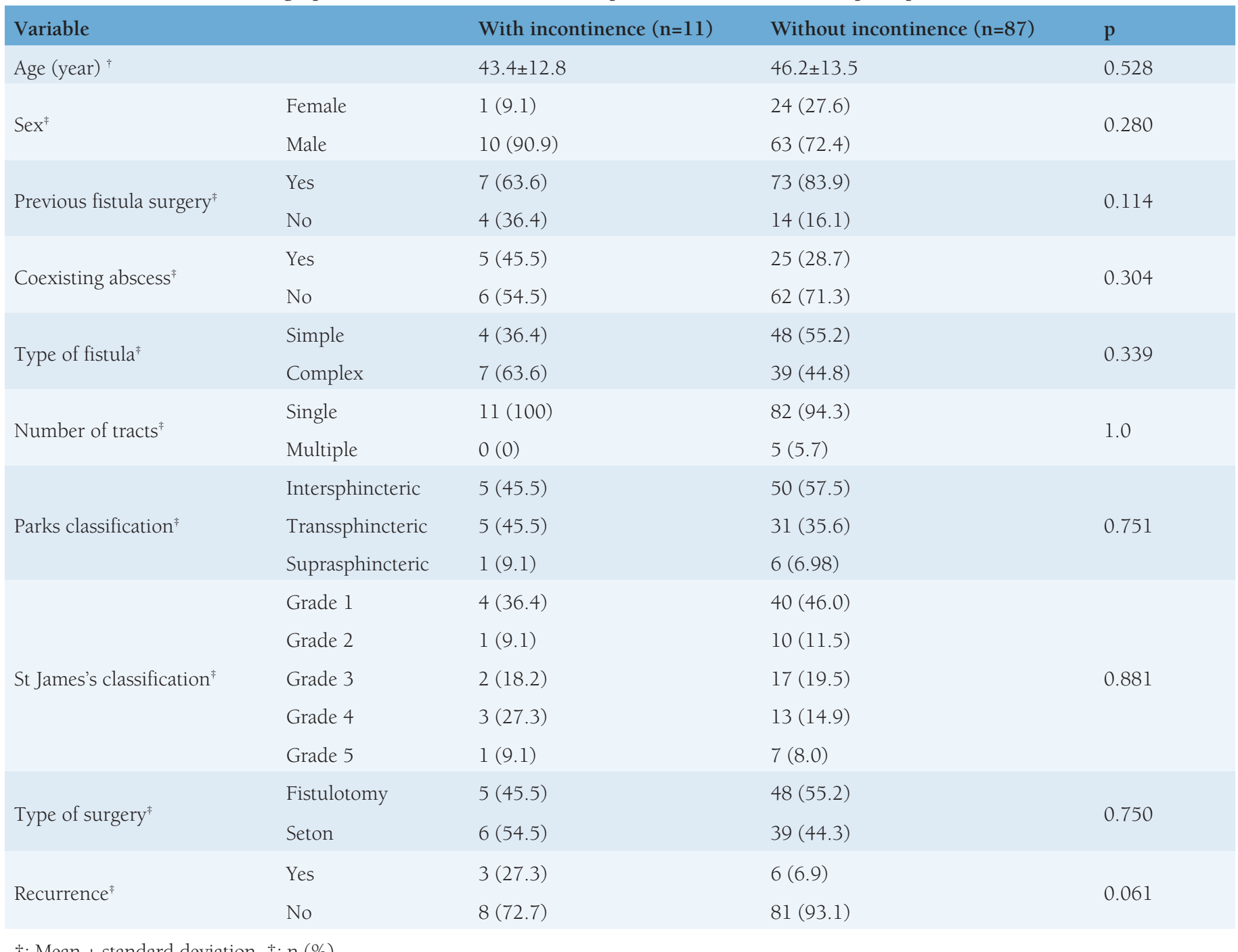

performed for patients who had recurrence and were fully cured. Thus, the healing rate after seton placement was $100 \%$ in the present study.

In patients with primary seton placement $(n=45)$, the mean number of seton insertions was 1.5 (range: 1-3). The mean time for the removal of seton was 13.7 weeks (range: 5-30 weeks). A total of 67 extra surgical procedures were performed in the seton placement group, whereas five refistulotomy operations were performed in the fistulotomy group (Figure 1). In the seton placement group, re-seton placement $(n=33)$ and fistulotomy $(n=30)$ were the most common procedures conducted. Fistulotomy was repeated in five patients in the fistulotomy group.

Thrombosed haemorrhoids and postoperative bleeding, which were treated conservatively, developed in two and one patient, respectively. The mean healing time was significantly longer in the seton placement and rectal advancement flap procedure subgroups as $17.5 \pm 5.4$ weeks and $21.0 \pm 1.4$ weeks, respectively, when compared with $7.1 \pm 1.5$ weeks and $9.9 \pm 3.2$ weeks in the outward displacement and fistulotomy groups, respectively $(\mathrm{p}<0.001)$.

\section{Discussion}

In this study, we have reported the long-term outcomes of the surgical treatment of anal fistula in terms of the rates of recurrence and incontinence. Fistulotomy and seton placement were performed in $53(54.1 \%)$ and 45 patients $(45.9 \%)$, respectively. The rates of recurrence and incontinence were $9.2 \%$ and $11.2 \%$, respectively. The patient, surgery and fistula-related factors were not found to be significantly associated with the development of recurrence and postoperative incontinence in the present study. All fistulas were healed at a median follow-up time of 33 months. In the fistulotomy group, five extra procedures 
Table 6. Demographic and clinical features and postoperative outcomes of the patients who underwent primary seton placement $(n=45)$

\begin{tabular}{|c|c|c|c|c|c|}
\hline \multirow[b]{2}{*}{ Variable } & & \multicolumn{4}{|c|}{ Type of surgery following seton placement } \\
\hline & & $\begin{array}{l}\text { Spontaneous } \\
\text { removal }(n=9)\end{array}$ & Re-seton $(n=23)$ & $\begin{array}{l}\text { Flap procedure } \\
(\mathrm{n}=2)\end{array}$ & $\begin{array}{l}\text { Fistulotomy } \\
(n=11)\end{array}$ \\
\hline Age $(\text { year })^{\dagger}$ & & $45.0 \pm 14.8$ & $44.2 \pm 14.9$ & $51.5 \pm 6.4$ & $44.9 \pm 10.7$ \\
\hline \multirow{2}{*}{$\operatorname{Sex}^{\ddagger}$} & Female & $4(44.4)$ & $7(30.4)$ & $0(0)$ & $3(27.3)$ \\
\hline & Male & $5(55.6)$ & $16(69.6)$ & $2(100)$ & $8(72.7)$ \\
\hline Previous fistula surgery ${ }^{\ddagger}$ & & $3(33.3)$ & $6(26.1)$ & $2(100)$ & $5(45.5)$ \\
\hline Coexisting abscess ${ }^{\ddagger}$ & Yes & $3(33.3)$ & $14(60.9)$ & $1(50)$ & $4(36.4)$ \\
\hline \multirow{2}{*}{ Number of $\operatorname{tracts}^{\ddagger}$} & Single & $8(88.9)$ & $21(91.3)$ & $2(100)$ & $9(81.8)$ \\
\hline & Multiple & $1(11.1)$ & $2(8.7)$ & $0(0)$ & $2(18.2)$ \\
\hline \multirow{2}{*}{ Type of fistula ${ }^{\ddagger}$} & Simple & $0(0)$ & $0(0)$ & $0(0)$ & $1(9.1)$ \\
\hline & Complex & $9(100)$ & $23(100)$ & $2(100)$ & 10 \\
\hline \multirow{3}{*}{ Parks classification $^{\ddagger}$} & Intersphincteric & $3(33.3)$ & $0(0)$ & $0(0)$ & $1(9.1)$ \\
\hline & Transsphincteric & $6(66.7)$ & $18(78.3)$ & $0(0)$ & 10 \\
\hline & Suprasphincteric & $0(0)$ & $5(21.7)$ & $2(100)$ & 0 \\
\hline \multirow{5}{*}{ St James's classification ${ }^{\ddagger}$} & Grade 1 & $3(33.3)$ & $0(0)$ & $0(0)$ & $1(9.1)$ \\
\hline & Grade 2 & $0(0)$ & $0(0)$ & $0(0)$ & $0(0)$ \\
\hline & Grade 3 & $6(66.7)$ & $5(21.7)$ & $0(0)$ & $7(63.6)$ \\
\hline & Grade 4 & $0(0)$ & $12(52.2)$ & $0(0)$ & $3(27.3)$ \\
\hline & Grade 5 & $0(0)$ & $6(26.1)$ & $2(100)$ & $0(0)$ \\
\hline Recurrence $^{\ddagger}$ & & $0(0)$ & $3(13.0)$ & $0(0)$ & $1(9.1)$ \\
\hline Postoperative incontinence ${ }^{\ddagger}$ & & $0(0)$ & $6(26.1)$ & $0(0)$ & $0(0)$ \\
\hline Healing time (month) ${ }^{\dagger}$ & & $7.1 \pm 1.5$ & $17.5 \pm 5.4$ & $21.0 \pm 1.4$ & $9.9 \pm 3.2$ \\
\hline
\end{tabular}

$\dagger:$ Mean \pm standard deviation, $¥: \mathrm{n}(\%)$

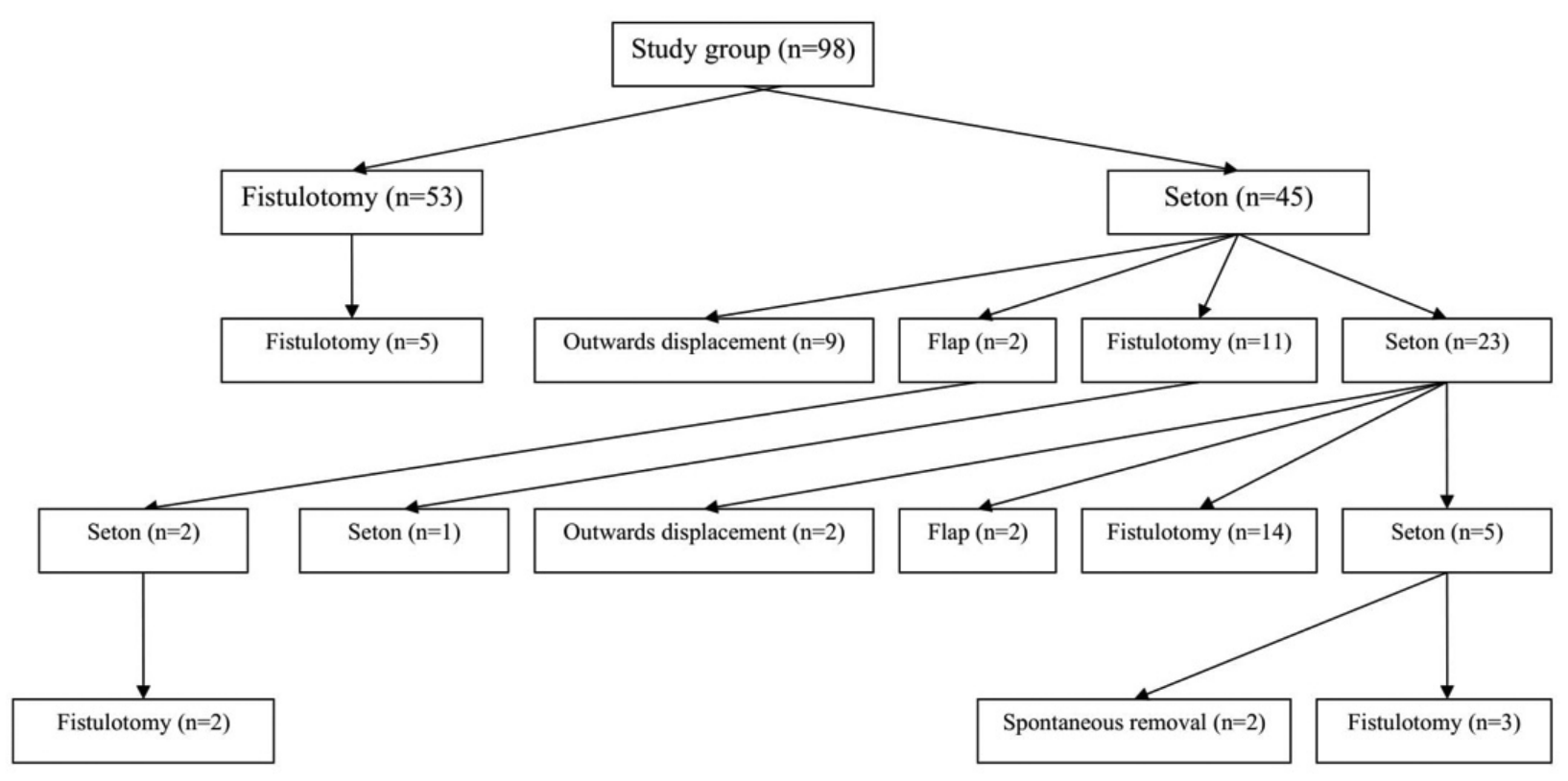

Figure 1. Schematic representation of the study groups 
were performed, while a total of 67 extra surgical procedures were performed in the seton placement group.

The reduced recurrence rates and safeguarding of the sphincter muscles have been regarded as the major measurements for the success of anal fistula surgery. 3.5 The recurrence rates after anal fistula surgery has been reported to be $2.5 \%$ to $57.1 \%$ depending on the type of fistula and the surgical techniques used as well as the duration of followup time..$^{5}$ Meta-analyses and large-scale studies revealed that high transsphincteric fistula with/without supralevator extension, unidentified internal opening, the presence of a horseshoe-formed abscess, more than one fistula tracts, anterior fistula, seton placement surgery and prior anal surgery are the significant risk factors for recurrence. ${ }^{13,14}$ It has also been mentioned that true incidence rates become more evident after longer follow-up periods. ${ }^{5}$ Although our median follow-up time (33 months) can be regarded as sufficient to evaluate the true incidence rate, we could not find any significant associations between the demographic and clinical factors, except for the age of the patients and the recurrence, in the present study. Although the age of the patients with recurrence was significantly lower, no plausible explanation for this result seems concrete. The inclusion of all types of fistula and different surgical techniques may yield insignificant findings. In addition, the number of patients in each subgroup may be regarded as insufficient to conduct any statistical analysis. Therefore, large-scale studies are needed to evaluate the risk factors for recurrence following anal fistula surgery.

As per past studies, the rates of recurrence and incontinence vary widely depending on the type of fistula and the surgical procedures used. In Andreou's study ${ }^{5}$ the reported recurrence rate following fistulotomy is $12 \%$. The authors speculated that the presence of high fistula in almost onethird of the patients led to such a high rate. In Gang's study ${ }^{7}$, seven recurrences (2\%) fully cured after re-fistulotomy were recorded. Most of the fistulas (63.7\%) treated via fistulotomy were simple. We also performed the fistulotomy technique more frequently for the intersphincteric type of anal fistulas, with five recurrences (9.4\%), all of which healed after refistulotomy. Although there was no significant impact of the type of fistula defined as both Parks and St. James classification on the development of recurrence in our study, we believe that a preoperative, accurate detection of the type of fistula may be more helpful to tailor the optimum treatment modality, considering the higher recurrence rates after fistulotomy specifically performed for high anal fistula. The variable recurrence rates of up to $22 \%$ after setonbased surgeries have been reported. ${ }^{13}$ In studies using loose or draining setons for anal fistula, the authors reported recurrence rates of approximately $10 \%{ }^{3,8,15}$ In the present study, the recurrence rate in the seton placement group was found to be $8.9 \%$. Our rates were believed to be comparable with those of previously reported studies. However, it should be considered that the recurrence rates following seton placement may be related to the type of seton material, insufficient drainage from the internal fistula hole and the discharge from the external fistula hole. ${ }^{8}$

A combination of fistulectomy or fistulotomy and pulling seton was employed for treating high-type anal fistula. ${ }^{16,17}$ In studies using combined approaches, $5 \%-17.2 \%$ of the patients developed recurrence of the fistula. Considering these variables recurrence rates in the studies using different surgical approaches, it is evident that there should be several confounding demographic, clinical and operative variables. Therefore, it is difficult to compare the outcomes of different studies to determine the ideal surgical approach for anal fistula.

The incontinence rates varying from $3.2 \%$ to $25.2 \%$ have been reported after seton-based surgeries. ${ }^{13,17,18}$ For instance, Izadpanah et al. ${ }^{17}$ reported 3\% of transient flatus type of incontinence after fistulectomy with pulling seton for transsphincteric and suprasphincteric type of fistulas. The authors speculated that minimal damage to external anal sphincter via intermittent pressure on the fistulous tracts is the major reason for the low rate of faecal incontinence in their techniques. A faecal incontinence rate of 3.2\% was reported in a study using fistulotomy and loose seton placement for high transsphincteric fistulas. ${ }^{13}$ Cutting seton was used as an alternative surgical approach for high anal fistulas with controversial outcomes. ${ }^{5,19,20}$ Raslan et al. ${ }^{19}$ reported a recurrence rate of $9.8 \%$, and the distribution to incontinence to flatus was similar to that in the present study. However, as we used a loose seton approach, we cannot compare the results obtained with the two seton techniques.

Serial seton placement followed by fistulotomy is another approach that is used for treating complex fistulas. The technical details have been described by Wang et al. ${ }^{3}$ The authors recommended timely postoperative examinations at 2-3-week intervals so as to avoid the premature healing of the openings. At the final stage, they performed fistulotomy with marsupialisation of the wound edges. No faecal incontinence was reported in their study. We used a similar approach in our study. In almost half of the patients in the seton placement group, re-seton placement (with a second seton) was performed. In five patients, we replaced the second setons with a third one. After the serial seton placements, fistulotomy was performed as the final procedure in most of the cases. Considering the results obtained, such a staged approach may be considered for application in select cases. In the present study, extra surgical procedures were required 
in patients with seton placement. A total of 67 re-operations were performed in 45 patients with primary seton placement. In addition, the mean number of seton insertions was 1.5, in accordance with the results of the Wang's study. ${ }^{3}$ Due to the fact that the ideal surgical technique is not known yet, information about the patients on the re-operations during the healing time and in case of recurrences should be performed.

The measurement of postoperative incontinence can be performed using several patient-reported outcome scales or an objective examination, such as anal manometry or endoanal ultrasonography. ${ }^{5}$ Although non-weighted scales such as the Wexner score or the Cleveland Clinic Faecal Incontinence Severity Index can be highly subjective, comparison of the preoperative and postoperative scores reflect the overall faecal incontinence status of the patients and their quality of life. ${ }^{5,21}$ Moreover, reporting or collection bias by the surgeons who act as the primary assessors and an assiduous data collection were also questioned. ${ }^{21}$ However, we collected data pre- and postoperatively and detected a significant decrease between the postoperative and preoperative Wexner scores.

The retrospective nature of this single-institution study was inherently associated with the risk of selection bias, which can be considered as considered was regarded as the main limitation. We compared two main surgical techniques that were performed as the primary surgical approach, whereas the inclusion of all types of fistulas was another important factor studied. Furthermore, as per the institutional policy, we did not use minimally invasive, alternative sphinctersaving procedures including fibrin glue, anal fistula plug and laser closure of anal fistula (FiLaC) for the treatment of anal fistula. The limited number of patients with each specific type of fistula and the subgroups following seton placement prevented the detailed analysis for each subset. Although all operations were performed by a member of our specialised coloproctology unit, we did not apply a predetermined standard algorithm for all patients. However, the presence of both preoperative and postoperative Wexner scores for the evaluation of faecal incontinence status of the patients and the longer follow-up period were the main strengths of the study.

\section{Conclusion}

In conclusion, patient, surgery and fistula-related factors were not significantly associated with the development of recurrence and postoperative incontinence following surgical treatment of anal fistula. However, we demonstrated that it can be possible to treat anal fistula by using different surgical approaches with acceptable rates of recurrence and incontinence. A staged surgical approach involving serial seton placements, followed by fistulotomy, may thus be a reliable technique for patients with complex fistulas. However, the ideal surgical approach continues to remain an obscure issue that necessitates large-scale prospective studies.

\section{Ethics}

Ethics Committee Approval: The local ethical committee approved the study (Ethical Committee for Clinical Studies, Karadeniz Techinical University, Faculty of Medicine, 21.01.2015/2020-138).

Informed Consent: The requirement for written consent from the patients was waived by the local ethical committee due to the retrospective design of the study and the assurance of data anonymity.

Peer-review: Externally and internally peer reviewed.

Financial Disclosure: The author declared that this study received no financial support.

\section{References}

1. García-Olmo D, Van Assche G, Tagarro I, Diez MC, Richard MP, Khalid JM, van Dijk M, Bennett D, Hokkanen SRK, Panés J. Prevalence of Anal Fistulas in Europe: Systematic Literature Reviews and Population-Based Database Analysis. Adv Ther 2019;36:3503-3518.

2. Isik O, Gulcu B, Ozturk E. Long-term Outcomes of laser ablation of fistula tract for fistula-in-ano: a considerable option in sphincter preservation. Dis Colon Rectum 2020;63:831-836.

3. Wang C, Rosen L. Management of low transsphincteric anal fistula with serial setons and interval muscle-cutting fistulotomy. J Integr Med 2016;14:154-158

4. Dutta G, Bain J, Ray AK, Dey S, Das N, Das B. Comparing Ksharasutra (Ayurvedic Seton) and open fistulotomy in the management of fistula-inano. J Nat Sci Biol Med 2015;6:406-410.

5. Andreou C, Zeindler J, Oertli D, Misteli H. Longterm outcome of anal fistula - A retrospective study. Sci Rep 2020;10:1-7.

6. Visscher AP, Schuur D, Roos R, Van der Mijnsbrugge GJ, Meijerink WJ, Felt-Bersma RJ. Long-term follow-up after surgery for simple and complex cryptoglandular fistulas: fecal incontinence and impact on quality of life. Dis Colon Rectum 2015;58:533-539.

7. Garg P. Is fistulotomy still the gold standard in present era and is it highly underutilized?. An audit of 675 operated cases. Int J Surg 2018;56:26-30.

8. Jafarzadeh J, Najibpoor N, Salmasi A. A comparative study on the effectiveness of rectal advancement flap and seton placement surgeries in patients with anal fistula on the rate of recurrence, incontinence and infection. J Family Med Prim Care 2019;8:3591-3594.

9. Omar W, Alqasaby A, Abdelnaby M, Youssef M, Shalaby M, Anwar AbdelRazik, Emile SH. Drainage Seton Versus External Anal Sphincter-Sparing Seton After Rerouting of the Fistula Tract in the Treatment of Complex Anal Fistula: A Randomized Controlled Trial. Dis Colon Rectum 2019;62:980987.

10. Anan M, Emile SH, Elgendy H, Shalaby M, Elshobaky A, Abdel-Razik MA, Elbaz SA, Farid M. Fistulotomy with or without marsupialisation of wound edges in treatment of simple anal fistula: a randomised controlled trial. Ann R Coll Surg Engl 2019;101:472-478.

11. Farag AFA, Elbarmelgi MY, Mostafa M, Mashhour AN. One stage fistulectomy for high anal fistula with reconstruction of anal sphincter without fecal diversion. Asian J Surg 2019;42:792-796. 
12. El-Said M, Emile S, Shalaby M, Abdel-Razik MA, Elbaz SA, Elshobaky A, Elkaffas H, Khafagy W. Outcome of Modified Park's Technique for Treatment of Complex Anal Fistula. J Surg Res 2019;235:536-542.

13. Emile SH, Elfeki H, Thabet W, Sakr A, Magdy A, Abd El-Hamed TM, Omar W, Khafagy W. Predictive factors for recurrence of high transsphincteric anal fistula after placement of seton. J Surg Res 2017;213:261-268.

14. Mei Z, Wang Q, Zhang Y, Liu P, Ge M, Du P, Yang W, He Y. Risk Factors for Recurrence after anal fistula surgery: A meta-analysis. Int J Surg 2019;69:153-164.

15. Daodu OO, O'Keefe J, Heine JA. Draining setons as definitive management of fistula-in-ano. Dis Colon Rectum 2018;61:499-503.

16. Liu H, Tang X, Chang Y, Li A, Li Z, Xiao Y, Zhang Y, Pan Z, Lv L, Lin M, Yin L, Jiang H. Comparison of surgical outcomes between video-assisted anal fistula treatment and fistulotomy plus seton for complex anal fistula: A propensity score matching analysis - Retrospective cohort study. Int J Surg 2020;75:99-104.
17. Izadpanah A, Rezazadehkermani M, Hosseiniasl SM, Farghadin A, Ghahramani L, Bananzadeh A, Roshanravan R, Izadpanah A. Pulling Seton: Combination of mechanisms. Adv Biomed Res 2016;5:68.

18. Lim CH, Shin HK, Kang WH, Park CH, Hong SM, Jeong SK, KimJY, Yang HK. The use of a staged drainage seton for the treatment of anal fistulae or fistulous abscesses. J Korean Soc Coloproctol 2012;28:309-314.

19. Raslan SM, Aladwani M, Alsanea N. Evaluation of the cutting seton as a method of treatment for anal fistula. Ann Saudi Med 2016;36:210-215.

20. Shirah BH, Shirah HA. The impact of the outcome of treating a high anal fistula by using a cutting seton and staged fistulotomy on Saudi Arabian patients. Ann Coloproctol 2018;34:234-240.

21. Hall JF, Bordeianou L, Hyman N, Read T, Bartus C, Schoetz D, Marcello PW. Outcomes after operations for anal fistula: results of a prospective, multicenter, regional study. Dis Colon Rectum 2014;57:1304-1308. 